\title{
Autologous bone marrow cell therapy for peripheral arterial disease
}

This article was published in the following Dove Press journal:

Stem Cells and Cloning:Advances and Applications

5 September 2012

Number of times this article has been viewed

\section{Botti \\ C Maione \\ A Coppola \\ $\checkmark$ Sica \\ G Cobellis}

Department of General Pathology, Second University of Naples, Naples, Italy
Correspondence: Gilda Cobellis Department of General Pathology, Second University of Naples,

Via Luigi De Crecchio 7, 80138 Napoli, Italy

Tel $+3908|566568|$

Fax+3908I 292399

Email g.cobellis@unina2.it
Abstract: Inadequate blood supply to tissues caused by obstruction of arterioles and/or capillaries results in ischemic injuries - these injuries can range from mild (eg, leg ischemia) to severe conditions (eg, myocardial infarction, stroke). Surgical and/or endovascular procedures provide cutting-edge treatment for patients with vascular disorders; however, a high percentage of patients are currently not treatable, owing to high operative risk or unfavorable vascular involvement. Therapeutic angiogenesis has recently emerged as a promising new therapy, promoting the formation of new blood vessels by the introduction of bone marrow-derived stem and progenitor cells. These cells participate in the development of new blood vessels, the enlargement of existing blood vessels, and sprouting new capillaries from existing blood vessels, providing evidence of the therapeutic utility of these cells in ischemic tissues. In this review, the authors describe peripheral arterial disease, an ischemic condition affecting the lower extremities, summarizing different aspects of vascular regeneration and discussing which and how stem cells restore the blood flow. The authors also present an overview of encouraging results from early-phase clinical trials using stem cells to treat peripheral arterial disease. The authors believe that additional research initiatives should be undertaken to better identify the nature of stem cells and that an intensive cooperation between laboratory and clinical investigators is needed to optimize the design of cell therapy trials and to maximize their scientific rigor. Only this will allow the results of these investigations to develop best clinical practices. Additionally, although a number of stem cell therapies exist, many treatments are performed outside international and national regulations and many clinical trials have been not registered on databases such as ClinicalTrials.gov or EudraCT. Therefore, more rigorous clinical trials are required to confirm the first hopeful results and to address the challenging issues.

Keywords: adult stem cells, critical limb ischemia, bone marrow transplantation, therapeutic angiogenesis

\section{What is peripheral arterial disease?}

Peripheral arterial disease (PAD) is a common circulatory problem in which narrowed arteries reduce blood flow to the limbs, especially the legs. The most common causes of PAD are atherosclerosis obliterans (ASO) and thromboangiitis obliterans (TAO). ${ }^{1}$

Two major classification systems are currently used to evaluate the spectrum of symptoms: (1) the Fontaine classification, not used in everyday clinical practice but useful for research purposes, and (2) the Rutherford classification, more commonly cited in recent publications in the field of vascular medicine (Table 1). The American College of Cardiology/American Heart Association 2005 guidelines noted the usefulness of the Rutherford classification for standardized communication between clinicians. ${ }^{1}$ 
Table I Two classifications of peripheral arterial disease (PAD): Fontaine and Rutherford

\begin{tabular}{|c|c|c|c|c|c|c|}
\hline \multicolumn{2}{|l|}{ PAD } & \multicolumn{2}{|c|}{ Fontaine } & \multicolumn{3}{|c|}{ Rutherford } \\
\hline Symptoms & Pathophysiology & Stage & Clinical & Grade & Category & Clinical \\
\hline $\begin{array}{l}\text { Fortuitous discovery of } \\
\text { aortic and iliac calcifications }\end{array}$ & $\begin{array}{l}\text { ATS plaques } \\
\text { Plaques at risk (inflammation } \\
\text { of ATS plaques) } \\
\text { Atherothrombosis }\end{array}$ & I & Asymptomatic & 0 & 0 & Asymptomatic \\
\hline $\begin{array}{l}\mathrm{ACD}>200 \mathrm{~m} \\
\text { Recovery time }<2 \text { minutes }\end{array}$ & $\begin{array}{l}\text { Discrepancy between oxygen } \\
\text { demand and arterial supply }\end{array}$ & Ila & Intermittent claudication & 1 & I & $\begin{array}{l}\text { Intermittent } \\
\text { claudication }\end{array}$ \\
\hline $\begin{array}{l}\mathrm{ACD} \leq 200 \mathrm{~m} \\
\text { Recovery time }>2 \text { minutes }\end{array}$ & $\begin{array}{l}\text { Higher discrepancy between } \\
\text { oxygen demand and arterial supply }\end{array}$ & Illb & $\begin{array}{l}\text { Moderate or severe } \\
\text { claudication }\end{array}$ & 1 & 2 & $\begin{array}{l}\text { Moderate } \\
\text { claudication }\end{array}$ \\
\hline $\begin{array}{l}\mathrm{ACD}<100 \mathrm{~m} \\
\text { Recovery time }>2 \text { minutes }\end{array}$ & $\begin{array}{l}\text { Higher discrepancy between oxygen } \\
\text { demand and arterial supply } \\
\text { Acidosis }\end{array}$ & & & 1 & 3 & $\begin{array}{l}\text { Severe } \\
\text { claudication }\end{array}$ \\
\hline Ischemic rest pain & Severe skin hypoxia and acidosis & III & $\begin{array}{l}\text { Ischemic rest pain } \\
\text { Critical limb ischemia }\end{array}$ & II & 4 & $\begin{array}{l}\text { Ischemic rest pain } \\
\text { Critical limb ischemia }\end{array}$ \\
\hline Necrosis & $\begin{array}{l}\text { Severe skin hypoxia and acidosis } \\
\text { Infection }\end{array}$ & IV & Ischemic ulceration & III & 5 & Minor tissue loss \\
\hline Gangrene & $\begin{array}{l}\text { Severe skin hypoxia and acidosis } \\
\text { Infection }\end{array}$ & & Tissue loss and gangrene & III & 6 & Major tissue loss \\
\hline
\end{tabular}

Abbreviations: ACD, absolute claudication distance; ATS, atherosclerotic.

Disease staging and classification systems are important for clinical management of these patients. Based on the severity of symptoms, usually two distinct clinical presentations are distinguished in PAD patients: (1) intermittent claudication, characterized by intermittent pain in leg muscles when the person walks, and (2) critical limb ischemia (CLI), a more severe form of PAD, characterized by pain at rest, nonhealing wounds, and gangrene. After 1 year, $30 \%$ of patients with CLI will lose their leg and $25 \%$ will die. ${ }^{2}$

The incidence of CLI in Western societies is approximately 220 new cases per million people per year, and, with an aging population, the population at risk is expected to increase because of persistent rates of tobacco abuse and an increase in diabetes. ${ }^{2}$ Fifty percent of diabetics ( $7 \%$ of the world population in 2010) suffer from PAD, which may lead to amputation due to CLI. ${ }^{3}$ Moreover, smoking, hypertension, dyslipidemia, a sedentary lifestyle, and a genetic predisposition all contribute to the development of PAD., ${ }^{4,5}$

\section{Current treatments for PAD}

Revascularization, either surgical or endovascular, is the gold standard treatment for patients with severe PAD. However, despite advances in surgical and endovascular techniques, ${ }^{6}$ more than $30 \%$ of patients do not qualify as candidates for revascularization because of excessive operative risk or adverse vascular involvement. Furthermore, the presence of extensive atherosclerotic plaques in the tibial and/or peroneal arteries renders revascularization unsuccessful. These patients are left to medical therapy, which may only slow disease progression, and the only remaining alternative for relief of rest pain or gangrene is amputation of the affected leg.

An estimated 120-500 amputations are performed per million people per year, and one-quarter of these patients require long-term institutional care or professional assistance at home. ${ }^{2}$ Medical therapy is limited to antithrombotic therapy, ${ }^{7}$ the prostaglandin analogue iloprost, ${ }^{8}$ or recently to cilostazol. Cilostazol has been found to be effective for the treatment of intermittent claudication. This compound has several beneficial effects on platelet aggregation, serum lipids, and endothelial cells (ECs), but how these might relate to improvements in walking is not entirely understood. ${ }^{9}$ Thus, there is a critical need to develop novel strategies to promote neovascularization in patients with CLI who are not candidates for conventional treatments.

In 1997, Asahara et $\mathrm{al}^{10}$ made a big step forward when they identified a class of bone marrow-derived circulating endothelial progenitor cells (EPCs) that contribute to angiogenesis and/or vasculogenesis in ischemic tissues. ${ }^{11}$ Since then, several studies have reported the capability of stem and progenitor cells to promote neovascularization, reducing ischemic damages. ${ }^{12,13}$ Encouraging results of several clinical studies have rapidly demonstrated the beneficial effects of autologous stem cell transplantation in patients affected by CLI. Clinical improvements were observed in objective and subjective measurements of perfusion (ie, transcutaneous oxygen tension $\left[\mathrm{TcPO}_{2}\right]$ and laser Doppler flowmetry [LDF]), pain reduction, increased pain-free total walking distance, and decreased rate of amputation. . $^{314-69}$ 


\section{What is vascular regeneration?}

Vascular regeneration involves the restoration of normal vascular function and structure and the growth of new blood vessels. This includes a plethora of processes, such as the distribution of blood flow via the formation of collateral networks; the response of newly generated vessels to hemodynamic, humoral, and local tissue factors; the modulation of the immune response and the trafficking of circulating cells; and the permeation of nutrients and macromolecules through the microvasculature, which can in turn have trophic effects on blood fluidity and hemostasis. ${ }^{9}$ Vascular regeneration is also important in a variety of processes: during embryonic organogenesis and organ growth in born individuals, in the course of restoration of blood supply to ischemic tissues, and in the establishment of blood supply to tumours. ${ }^{70}$

Neovascularization involves the growth of new structures from preexisting vessels by migration, proliferation, and differentiation of progenitor cells and the interplay between growth factors and cytokines. The process of neovascularization comprises three distinct phenomena: (1) vasculogenesis, (2) angiogenesis, and (3) arteriogenesis. ${ }^{70}$

The essential mechanism responsible for new blood vessel formation in adults is based on neoangiogenesis. During angiogenesis, ECs present in vessel walls are activated in response to various stimuli and begin to relase various growth factors, the angiopoietins (Ang1 and Ang2) and Vascular Endothelial Growth Factor (VEGF), which play a crucial role in this process. While Ang1 and Ang2 participate in the "stabilization" of the newly formed vessels, VEGF exerts its pro-angiogenic function by binding to one of its receptors, specifically the VEGF receptor 2 or kinase (VEGFR2 or KDR) insert domain receptor, expressed exclusively by ECs and their precursors. This binding triggers a cascade of events that leads to the formation of new blood vessels and which comprises the migration of ECs into the surrounding tissue in response to angiogenic chemokines; proliferation and differentiation of EPCs; and recruitment of support cells such as pericytes for small capillaries and smooth muscle cells for larger vessels.

The main factor inducing angiogenesis in adults is the availability of oxygen, through the activation of hypoxiainducible factors. ${ }^{71,72}$

\section{Stem cells with angiogenic potential}

Stem cells are defined as cells with the capacity to self-renew and to generate differentiated cells and are divided into two types: embryonic and adult stem cells. ${ }^{73}$ Adult stem cells are partially lineage-committed cells and have the capacity to give rise to specialized cells. For this feature, adult stem cells are so-called multipotent cells - as opposed to pluripotent cells (ie, embryonic stem cells), which can give rise to all the cell types in the body. Adult stem cells include three different groups: (1) the bone marrow stem cells, (2) the circulating pool of stem/progenitor cells (also derived from the bone marrow), and (3) the tissue-resident stem cells. ${ }^{74}$

Bone marrow stem cells include different types of progenitor cells, such as multipotent adult progenitor cells, mesenchymal stem cells (MSCs), and hematopoietic stem cells. The circulating pool of stem and progenitor cells contains a variety of cells, but the most relevant for vascular regeneration are the EPCs. Finally, the tissue-resident stem cells are present in almost all tissues in a quiescent state and can respond efficiently to different stimuli. ${ }^{74}$

Both EPCs and MSCs show promise for potential utility in therapeutic neovascularization. MSCs are reported to promote angiogenesis because of their capacity to stimulate EC migration and tube formation; furthermore, MSCs support neoangiogenesis, releasing soluble factors that contribute to stimulate angiogenesis. ${ }^{75}$

\section{What are the features of these cells?}

MSCs are a subset of cells that express on their surface specific molecules such as CD73, CD90, and CD105; MSCs also express CD54/CD102, CD166, and CD49 (alpha integrin), which regulate cell-to-cell interactions, and they do not express any hematopoietic and/or EPC surface markers. ${ }^{76}$ MSCs can be found in many fetal and adult tissues and are generally isolated from bone marrow, adipose tissue, umbilical cord blood, and compact bone. Furthermore, MSCs are able to migrate to and home to injured sites, where they act by differentiating into specific cells and by secreting trophic factors, which activate paracrine signaling. ${ }^{77}$ Moreover, these cells interact with the immune system, particularly modulating the immune response, apparently by inhibiting tumor necrosis factor-alpha (TNFa) and interferon-gamma (IFN- $\gamma$ ) and by increasing interleukin 10 (IL-10) ${ }^{78}$ This unique immunomodulatory property makes these cells suitable for both autologous and heterologous transplants, since they avoid and/or actively suppress eventual rejection of transplants. ${ }^{79}$

MSCs display a great therapeutic potential because of their capability to differentiate into muscle, neural precursors, cardiomyocytes, and perivascular cells. Perivascular cells (herein referred to as pericytes) are critical cells in vascular biology. Pericytes typically express alpha smooth muscle actin ( $\alpha$-SMA), platelet-derived growth factor receptor beta 
(PDGF- $\beta$ ), and nerve/glial antigen-2 (NG-2) proteoglycan. They are branched cells embedded within the basement membrane of capillaries and postcapillary venules, stabilizing the vessel wall. ${ }^{80}$ Pericytes are considered cells that control EC proliferation and migration, and thereby also the growth of new capillaries. In turn, ECs stimulate expansion and activation of the pericyte precursor cell population. The balance between ECs and pericytes is highly controlled by a series of signaling pathway mechanisms operating in an autocrine and/ or a paracrine manner. In pathological conditions in which angiogenic activity is impaired, pericytes and ECs could be partly responsible for abnormalities in blood vessels.

EPCs are adult hemangioblast-derived cells characterized by the expression of CD34, VEGF receptor 2, and CD133. These markers are expressed by precursor cells, but not by differentiated ones. ${ }^{81}$ In fact, as the hemangioblasts differentiate to become ECs, they downregulate the hematopoietic stem cell marker CD133 expression. ${ }^{81}$ EPCs can be isolated from human peripheral or umbilical cord blood and can also be found in bone marrow niches. EPCs have shown in vitro all the functional properties of ECs; moreover, EPCs have direct angiogenic action, supporting angiogenesis through their ability to secrete paracrine mediators. In this respect, several studies have shown that these cells release interleukins, growth factors, and chemokines that altogether regulate CD14-positive cells, accelerate vascular network formation, and enhance healing processes. ${ }^{82}$

Adult stem cells with angiogenic potential such as EPCs and MSCs will stimulate the production of new blood vessels, as shown in Figure 1.

\section{Cell therapy in PAD: clinical results}

Promotion of collateral vessel formation and angiogenesis in PAD patients is an important therapeutic strategy to minimize tissue injury associated with severe ischemia. The Therapeutic Angiogenesis using Cell Transplantation trial was the first report on the use of bone marrow-derived mononuclear cells in the treatment of PAD. ${ }^{14}$ Starting from this, the search of the literature yielded a total of 57 earlyphase clinical trials for a total of 1997 enrolled patients. The safety and feasibility of autologous cell transplantation has been reported in 1667 treated patients (Tables 2 and 3). Among these, a total of 303 diabetic patients with CLI and foot ulcers underwent cell therapy. The degree of ischemia varied throughout the groups, ranging from Rutherford category 4/Fontaine stage III through to severe CLI classified as Rutherford category 6/Fontaine stage IV.

Only a minority of trials $(n=13)$ included appropriate controls (Table 4). In these studies, the follow-up of the untreated or placebo group did not differ from that observed

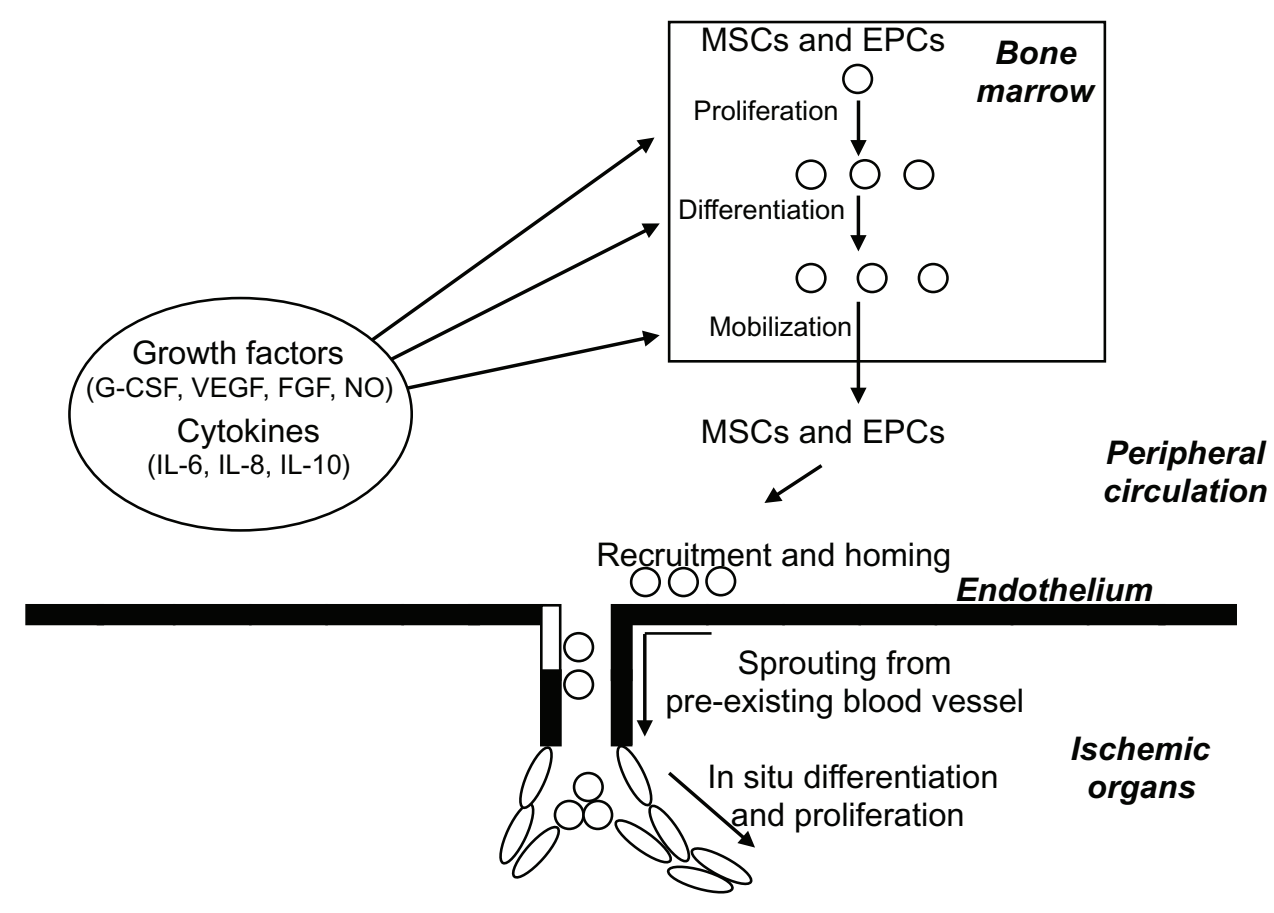

Figure I Schematic representation of neoangiogenesis promoted by circulating and bone marrow-resident stem cells.

Notes: Ischemia induces production of growth factors, cytokines, and hormones, which promotes proliferation, differentiation, and mobilization of mesenchymal stem cells (MSCs) and endothelial progenitor cells (EPCs) to form new vessels. In addition, the growth factors can stimulate EPCs sprouting from preexisting blood vessels.

Abbreviations: FGF, fibroblast growth factor; G-CSF, granulocyte colony-stimulating factor; IL, interleukin; NO, nitric oxide; VEGF, vascular endothelial growth factor. 
Table 2 Clinical trials with cell therapy in peripheral arterial disease (PAD)

\begin{tabular}{|c|c|c|c|c|c|c|}
\hline Published study & $\begin{array}{l}\text { Delivery } \\
\text { route }\end{array}$ & Condition & $\begin{array}{l}\text { Patients } \\
\text { (n) }\end{array}$ & Cell type & Follow-up time & $\begin{array}{l}\text { Improved functional } \\
\text { outcomes }\end{array}$ \\
\hline $\begin{array}{l}\text { Tateishi-Yuyama } \\
\text { et al }{ }^{14}\end{array}$ & IM & PAD, DM & 45 & BMCs or PB-MNCs & 4 and 24 weeks & $\begin{array}{l}A B I, T c P O_{2} \text {, rest pain, pain-free } \\
\text { walking time }\end{array}$ \\
\hline Esato et $\mathrm{al}^{15}$ & IA & PAD & 8 & BMCs & $\mathrm{N} / \mathrm{D}$ & Ulceration healing \\
\hline Saigawa et al ${ }^{16}$ & IM & PAD, DM & 8 & BMCs & 4 weeks & $\mathrm{ABI}, \mathrm{TcPO}_{2}$ \\
\hline Higashi et al ${ }^{17}$ & IM & PAD & 7 & BMCs or BM-MNCs & 4 and 24 weeks & $\begin{array}{l}\mathrm{ABI}, \mathrm{TcPO}_{2} \text {, pain-free walking } \\
\text { time }\end{array}$ \\
\hline Miyamoto et al ${ }^{18}$ & IM & CLI & 12 & BMCs and EPCs & N/D & $A B I$, pain-free walking time \\
\hline Huang et al ${ }^{19}$ & IM & PAD & 5 & PB-MNCs & 3 months & $A B I, L D F$ \\
\hline Kawamura et $\mathrm{a}^{20}$ & IM & PAD, CLI & 30 & PB-MNCs & N/D & $\mathrm{T}^{\circ} \mathrm{C}$ \\
\hline Lenk et $\mathrm{a}^{21}$ & IA & CLI & 7 & PB-MNCs & 20 weeks & $\begin{array}{l}\mathrm{ABI}, \mathrm{TCPO}_{2} \text {, rest pain, pain-free } \\
\text { walking time }\end{array}$ \\
\hline Huang et $\mathrm{a}^{22}$ & IM & CLI, DM & 28 & MPB-MNCs & 3 months & $A B I$, pain, ulcers \\
\hline Ishida et $\mathrm{al}^{23}$ & IM & PAD & 6 & MPB-MNCs & 4 and 24 weeks & $A B I$, ulcers \\
\hline Durdu et $\mathrm{a}^{24}$ & IM & PAD & 28 & BM-MNCs & 3 and 6 months & $\begin{array}{l}A B I \text {, rest pain, pain-free walking } \\
\text { time }\end{array}$ \\
\hline Koshikawa et $\mathrm{a}^{25}$ & IM & PAD & 7 & BM-MNCs & 6 months & $A B I$, pain, ulcers \\
\hline Arai et $\mathrm{al}^{26}$ & IM & PAD & 25 & BMCs & I month & $\mathrm{ABI}, \mathrm{TcPO}_{2}$ \\
\hline Miyamoto et a ${ }^{27}$ & IM & PAD, CLI & 8 & BM-MNCs & $\begin{array}{l}4 \text { weeks, } 4 \text { and } \\
7 \text { months, and } \\
\text { I year }\end{array}$ & Rest pain, ulcers \\
\hline Kawamura et $\mathrm{a}^{28}$ & IM & CLI & 92 & PB-MNCs & 6 weeks & Limb salvage, VEGF serum level \\
\hline Bartsch et $\mathrm{al}^{29}$ & $\mathrm{IM}$ and $\mathrm{IA}$ & PAD, CLI & 13 & BMCs & 2 and 13 months & $A B I$, pain-free walking distance \\
\hline Huang et $\mathrm{al}^{30}$ & IM & PAD & 150 & BM-MNCs or MPB-MNCs & 12 weeks & $A B I$, rest pain \\
\hline Kajiguchi et a $\left.\right|^{31}$ & IM & CLI & 7 & BM-MNCs or PB-MNCs & I month & $A B I$ \\
\hline Hernández et $\mathrm{a}^{32}$ & IM & CLI, DM & 12 & $\mathrm{BM}-\mathrm{MNCs}$ & 24 months & $\begin{array}{l}\mathrm{ABI}, \mathrm{SaO}_{2} \text {, pain-free walking time, } \\
\text { rest pain }\end{array}$ \\
\hline Saito et $\mathrm{al}^{33}$ & IM & PAD & 7 & BM-MNCs & $\mathrm{N} / \mathrm{D}$ & $\mathrm{TcPO}_{2}$ \\
\hline Matoba et $\mathrm{al}^{34}$ & IM & PAD & 115 & BM-MNCs & 3 years & $\begin{array}{l}\text { Pain, ulcers, pain-free walking } \\
\text { distance }\end{array}$ \\
\hline Napoli et $\mathbf{a}^{35}$ & IA & PAD & 18 & BM-MNCs & $\begin{array}{l}3,6,12 \text {, and } \\
18 \text { months }\end{array}$ & $\begin{array}{l}A B I \text {, ulcers, pain-free walking } \\
\text { distance }\end{array}$ \\
\hline Gu et $a^{36}$ & IM or IA & PAD, DM & 32 & BM-MNCs & 4 weeks & $\mathrm{ABI}, \mathrm{TcPO}_{2}$, limb salvage \\
\hline Chochola et $\mathrm{a}^{37}$ & IA & PAD, DM & 24 & BM-MNCs & I year & Limb salvage, wound healing \\
\hline Wester et $\mathrm{al}^{38}$ & IM & CLI & 8 & BMCs & 4 and 8 months & $\mathrm{ABI}, \mathrm{TcPO}_{2}$, ulcers \\
\hline $\begin{array}{l}\text { Van Tongeren } \\
\text { et } \mathrm{al}^{39}\end{array}$ & IM and IA & CLI & 27 & BMCs & 6 and 12 months & $\begin{array}{l}\text { Pain-free walking distance, } \\
A B I \text {, pain reduction }\end{array}$ \\
\hline De Vriese et al ${ }^{40}$ & IM & CLI & 16 & BM-MNCs & 12 weeks & $\mathrm{TcPO}_{2}$, pain reduction \\
\hline Cobellis et $\mathrm{al}^{41}$ & IA & PAD & 10 & BM-MNCs & 12 months & $A B I$, pain-free walking distance \\
\hline Motukuru et al ${ }^{42}$ & IM & PAD & 38 & BM-MNCs & 6 months & $\begin{array}{l}\text { Ulcer healing, limb salvage, } \\
\mathrm{ABI}, \mathrm{TcPO}_{2}\end{array}$ \\
\hline Amann et $\mathrm{al}^{43}$ & IM & CLI & 45 & BM-MNCs & 3 months & $\begin{array}{l}\text { Limb salvage, } A B I, T_{c P O} \text {, } \\
\text { pain-free walking distance }\end{array}$ \\
\hline Amann et $\mathrm{al}^{44}$ & IM & PAD & 51 & BM-MNCs & 6 months & $\begin{array}{l}\text { Limb salvage, } A B I, T_{c P O} \\
\text { pain-free walking distance }\end{array}$ \\
\hline Capiod et a $\left.\right|^{45}$ & IM & CLI & 24 & BM-MNCs or PB-MNCs & $\mathrm{N} / \mathrm{D}$ & No clinical evaluation reported \\
\hline Franz et $\mathrm{a}^{46}$ & IM and IA & PAD & 9 & BM-MNCs & $\begin{array}{l}2 \text { weeks and } \\
3 \text { months }\end{array}$ & $\begin{array}{l}A B I \text {, pain reduction, ulcers, } \\
\text { limb salvage }\end{array}$ \\
\hline Franz et a $\left.\right|^{47}$ & $\mathrm{IM}$ and IA & PAD & 20 & BM-MNCs & 3 months & $\begin{array}{l}\text { ABI, pain reduction, ulcers, } \\
\text { limb salvage }\end{array}$ \\
\hline Zafarghandi et al ${ }^{48}$ & IM & CLI & 50 & BM-MNCs and G-CSF & 4 and 24 weeks & $A B I$, pain-free walking distance \\
\hline Procházka et a ${ }^{49}$ & IM & CLI, DF & 37 & BMSCs & 3 months & $\mathrm{LDF}, \mathrm{ABI}, \mathrm{TcPO}_{2}$, limb salvage \\
\hline Procházka et al ${ }^{3}$ & IM & PAD & 96 & BMSCs & 4 months & $A B I$, limb salvage \\
\hline $\begin{array}{l}\text { Lara-Hernandez } \\
\text { et a }{ }^{50}\end{array}$ & IM & CLI & 28 & Mobilized EPCs & $\begin{array}{l}14 \text { and } 18 \text { months } \\
\text { and I year }\end{array}$ & $A B I$, limb salvage \\
\hline Iso et $\mathrm{a}^{51}$ & IM & CLI & 13 & BM-MSCs & 4 months & $\mathrm{TcPO}_{2}$, rest pain \\
\hline
\end{tabular}


Table 2 (Continued)

\begin{tabular}{|c|c|c|c|c|c|c|}
\hline Published study & $\begin{array}{l}\text { Delivery } \\
\text { route }\end{array}$ & Condition & $\begin{array}{l}\text { Patients } \\
\text { (n) }\end{array}$ & Cell type & Follow-up time & $\begin{array}{l}\text { Improved functional } \\
\text { outcomes }\end{array}$ \\
\hline Sprengers et $\mathrm{al}^{52}$ & IA & CLI & 120 & BM-MNCs & 6 months & $\begin{array}{l}\text { Limb salvage, ulcers, rest pain, } \\
\mathrm{ABI}, \mathrm{TcPO}_{2}\end{array}$ \\
\hline Murphy et al ${ }^{53}$ & IM & CLI & 29 & BM-MNCs & I year & $\begin{array}{l}\text { First-toe pressure and toe- } \\
\text { brachial index increase, perfusion } \\
\text { index by computed tomography, } \\
\text { rest pain }\end{array}$ \\
\hline Walter et $\mathrm{al}^{54}$ & IA & CLI & 40 & BM-MNCs & 3 months & $A B I$, ulcer healing, rest pain \\
\hline lafrati et $\mathrm{al}^{55}$ & IM & CLI, DM & 48 & BMSCs & 12 weeks & $\begin{array}{l}\text { Limb salvage, pain, } A B I \text {, } \\
\text { Rutherford classification, quality } \\
\text { of life }\end{array}$ \\
\hline Idei et $\mathrm{al}^{56}$ & IM & CLI & 97 & BM-MNCs & 56 months & $\begin{array}{l}\mathrm{ABI}, \mathrm{TCPO}_{2} \text {, pain, amputation-free } \\
\text { survival rate }\end{array}$ \\
\hline $\begin{array}{l}\text { Ruiz-Salmeron } \\
\text { et } \mathrm{al}^{57}\end{array}$ & IA & CLI & 20 & BM-MNCs & 3 and 12 months & $\begin{array}{l}\text { Rutherford classification, } \\
\text { diabetic wound scales, } A B I \text {, } \\
\text { mortality rate }\end{array}$ \\
\hline Lu et $\mathrm{al}^{58}$ & IM & CLI, DM & 82 & BM-MNCs, BMSCs & 6 and 24 weeks & $\begin{array}{l}\text { Pain-free walking time, } \mathrm{ABI} \text {, } \\
\mathrm{TcPO}_{2} \text {, ulcers, limb salvage }\end{array}$ \\
\hline Gabr et $a^{59}$ & IM & CLI & 20 & BM-MNCs & 3 months & $\begin{array}{l}\text { Walking distance, rest pain, } \\
\text { skin condition, } A B I\end{array}$ \\
\hline Benoit et $\mathrm{al}^{60}$ & IM & CLI & 48 & BMSCs & 6 months & $\begin{array}{l}\text { Limb salvage, Rutherford } \\
\text { classification, } A B I \text {, pain }\end{array}$ \\
\hline Powell et $\mathrm{a}^{61}$ & IM & CLI & 86 & BMCs & 6 and 12 months & Limb salvage, TTF, wound healing \\
\hline Perin et $\mathrm{al}^{62}$ & IM & CLI & 21 & BM-MNCs & 6 and 12 weeks & $\begin{array}{l}\text { Rutherford classification, } \\
\mathrm{ABI}, \mathrm{TCPO}_{2} \text {, quality of life, } \\
\text { pain }\end{array}$ \\
\hline Smadja et $\mathrm{al}^{63}$ & IM & CLI & II & BM-MNCs & 6 and 12 months & $\begin{array}{l}\mathrm{TcPO}_{2} \text {, wound healing, } \\
\text { limb salvage }\end{array}$ \\
\hline Powell et $\mathrm{al}^{64}$ & IM & CLI & 77 & Multicellular therapy & 12 months & TTF, limb salvage \\
\hline Klepanec et $a^{65}$ & IM or IA & CLI & 41 & $\mathrm{BMCs}$ & 6 months & $\begin{array}{l}\text { Rutherford classification, } \mathrm{ABI} \text {, } \\
\mathrm{TcPO}_{2} \text {, pain, limb salvage, wound } \\
\text { healing }\end{array}$ \\
\hline Schiavetta et al $^{66}$ & IA & CLI, DM & 60 & BM-MNCs & 12 months & LDF, $\mathrm{TcPO}_{2}$, limb salvage \\
\hline
\end{tabular}

Abbreviations: $\mathrm{ABI}$, ankle-brachial index; BMCs, bone marrow cells; BMSCs, bone marrow stem cells; BM-MNCs, bone marrow-derived mononuclear cells; CLI, critical limb ischemia; DF, diabetic foot; DM, diabetes mellitus; EPCs, endothelial progenitor cells; G-CSF, granulocyte colony-stimulating factor; IA, intra-arterial injection; IM, intramuscular injection; LDF, laser Doppler flowmetry; MPB-MNCs, mobilized peripheral blood-derived mononuclear cells; N/D, not determined; PB-MNCs, peripheral blood-derived mononuclear cells; $\mathrm{SaO}_{2}$, arterial oxygen saturation; $\mathrm{T}^{\circ} \mathrm{C}$, temperature expressed in degrees $\mathrm{Celsius;} \mathrm{TcPO}_{2}$, transcutaneous oxygen tension; TTF, time to first occurrence of treatment failure; VEGF, vascular endothelial growth factor.

in several large population studies. ${ }^{2,83-87}$ In addition, the Edinburgh Artery Study defined the prevalence of asymptomatic and symptomatic PAD and related comorbidities in the general population. ${ }^{87}$ Therefore, since the progression of disease is well defined in CLI patients, the lack of an untreated or a placebo group - even if scientifically compelling - cannot diminish the significance of the studies.

Two sources of cells were used in these trials: (1) bone marrow aspiration $(n=46)$ and $(2)$ apheresis of peripheral blood with or without GSF stimulation $(n=11)$. The route of cell administration was intramuscular in 39 trials,

Table 3 Clinical trials with intralesional administration of stem cells in foot ulcers

\begin{tabular}{llllll}
\hline Published study & Condition & Patients $(\mathbf{n})$ & Cell type & Follow-up time & Improved functional outcomes \\
\hline $\begin{array}{l}\text { Vojtassák et al }{ }^{67} \\
\text { Dash et al }{ }^{68}\end{array}$ & DF & I & BMSCs & 29 days & Wound size and ulcer healing \\
Subrammaniyan et al ${ }^{69}$ & CLI & 6 & BMSCs & 3 months & $\begin{array}{l}\text { Wound size and pain-free walking } \\
\text { distance }\end{array}$ \\
& & 6 & BM-MNCs & 6 months & $\begin{array}{l}\text { ABI and pain-free walking distance, } \\
\text { limb salvage, ulcer healing, and rest pain }\end{array}$ \\
\hline
\end{tabular}

Abbreviations: $\mathrm{ABI}$, ankle-brachial index; BM-MNCs, bone marrow-derived mononuclear cells; BMSCs, bone marrow stem cells; CLI, critical limb ischemia; DF, diabetic foot; PAD, peripheral arterial disease. 
Table 4 Controlled clinical trials with cell therapy in peripheral arterial disease

\begin{tabular}{|c|c|c|c|c|}
\hline \multirow{2}{*}{$\begin{array}{l}\text { Published } \\
\text { study }\end{array}$} & \multirow[t]{2}{*}{ Year } & \multicolumn{3}{|l|}{ Patients } \\
\hline & & Total (N) & Treated (n) & Control (n) \\
\hline Powell et al ${ }^{64}$ & 2012 & 72 & 48 & 24 \\
\hline Benoit et $\mathrm{al}^{60}$ & 2011 & 48 & 34 & 14 \\
\hline Lu et a $\left.\right|^{58}$ & 2011 & 82 & 41 & 41 \\
\hline Powell et $\mathrm{a}^{61}$ & 2011 & 46 & 32 & 14 \\
\hline Idei et al ${ }^{56}$ & 2011 & 97 & 51 & 46 \\
\hline lafrati et $\mathrm{al}^{55}$ & 2011 & 48 & 34 & 14 \\
\hline Walter et al ${ }^{54}$ & 2011 & 40 & 19 & 21 \\
\hline Procházka et $\mathrm{al}^{3}$ & 2010 & 96 & 42 & 54 \\
\hline Sprengers et $\mathrm{a}^{52}$ & 2010 & 110 & 55 & 55 \\
\hline Cobellis et $\mathrm{al}^{41}$ & 2008 & 19 & 10 & 9 \\
\hline Bartsch et $\mathrm{a}^{29}$ & 2007 & 25 & 13 & 12 \\
\hline Arai et $\mathrm{a}^{26}$ & 2006 & 25 & 13 & 12 \\
\hline Huang et $\mathrm{a}^{22}$ & 2005 & 28 & 14 & 14 \\
\hline
\end{tabular}

intra-arterial in nine trials, and combined intra-arterial plus intramuscular in four trials (Table 2). Furthermore, two studies compared the therapeutic effects of intramuscular or intra-arterial delivery of bone marrow cells in patients with lower limb ischemia, showing similar beneficial results. ${ }^{36,65}$

To prevent clot formation, harvested cells were collected in the presence of anticoagulant. ${ }^{3,14-69}$ Intramuscular administration is usually performed through multiple injections at the level of limb muscles, while intra-arterial infusion is usually performed via classic femoral access. Three studies reported the use of intralesional administration of bone marrow-derived stem cells in 31 diabetic patients with foot ulcers, showing encouraging results (Table 3).

In general, bone marrow aspiration was well tolerated, and the most frequent adverse reaction was local pain or mild anemia. However, serious adverse reactions such as angina with ST segment depression were observed in a small number of patients. ${ }^{55}$

The average follow-up of these clinical studies was $8.4 \pm 9.55$ months. Considering all studies, the reported outcomes for therapeutic efficacy of cell therapy involved the ankle-brachial index, $\mathrm{TcPO}_{2}, \mathrm{LDF}$, pain-free walking distance, ulcer healing, and amputation-free survival. In all studies, symptoms improved after the procedure, as evidenced by clinical evaluation, relief of rest pain, and improvement by at least one level in Rutherford and Fontaine classifications. Furthermore, autologous cell therapy promoted amputationfree survival with an average of 7.8 months and promoted complete wound healing within 3 months in most patients with ulcers prior to bone marrow stem cell transplantation, in comparison with the natural history of PAD patients. Therefore, autologous transplantation of bone marrow-derived cells significantly improved both the objective and the subjective endpoints.

\section{Conclusion}

Herein, the authors provide the most comprehensive review of cell therapy trials describing the background and first results of stem and progenitor cell therapy in patients with CLI who are not suitable for revascularization. Both the principle, as far as it is understood, and the methods are described. Compelling evidence suggests that stem cell therapy may become a useful adjunct to the current treatment options. Because of poor prognosis and the increasing number of patients, there is a need for new therapeutic methods.

About 1997 patients without revascularization options were enrolled in these trials and 1667 patients were treated. Cell therapy significantly improved functional outcomes such as ankle-brachial index, $\mathrm{TcPO}_{2}$ or LDF, rest pain, pain-free walking distance, ulcer healing, and limb salvage. Although it is generally agreed that controlled trials yield more reliable results, the authors also included noncontrolled studies, which are the majority of published reports. The authors believe the main reason for this majority is that the authorized studies have chosen to treat end-stage patients, without other therapeutic options. The procedures are generally safe and well tolerated. Reported deaths were expected, given the severe underlying disease, and could not be directly attributed to cell therapy.

Challenges in this new therapeutic option still include open questions regarding cell number, phenotype, processing, route of optimal delivery, and frequency of application. The number of injected cells ranged from $4 \times 10^{6}$ to $10^{9}$ for bone marrow cells and from $7 \times 10^{7}$ to $3 \times 10^{9}$ for peripheral blood-derived mononuclear cells, with positive effects on blood perfusion, even when low cells were used. Nevertheless, no correlation study between clinical response and cell number has been performed so far, and no proven correlation exists between the phenotype of used cells and efficacy of neoangiogenesis. Answering these two points is critical to understanding which and how many cells are needed to obtain a clinical response.

The question of optimal delivery route remains open. The rationale behind the intramuscular injection is to generate a reservoir of cells near the ischemic area, which can be recruited by active paracrine mechanisms. The intra-arterial injection relies on the fact that the blood flow transports cells up to the ischemia site; however, it is not known how many cells are able to leave the blood stream to reach the ischemic area. Again, no correlation 
study between the two routes of administration has been performed, although the present trend is for intramuscular administration. It has been reported that the combination of both routes (intramuscular plus intra-arterial) ${ }^{39}$ has given substantial improvements in clinical outcomes, but this must be confirmed in exhaustive experiments in preclinical models.

In summary, over the past 10 years there has been considerable interest in stem cells, including extensive clinical activity involving stem cells. Unfortunately, the rationale for the clinical application of adult stem cells, particularly in regenerative medicine, has lagged behind initial laboratory observations. At this point, the authors believe that additional research initiatives should be undertaken to better identify the nature of stem cells and that an intensive cooperation between laboratory and clinical investigators is needed to optimize the design of cell therapy trials and to maximize their scientific rigor. Only this will allow the results of these investigations to develop best clinical practices.

Additionally, although a number of stem cell therapies exist, many treatments are performed outside international and national regulations and many clinical trials have been not registered on databases such as ClinicalTrials.gov or EudraCT. Therefore, more rigorous clinical trials are required to confirm the first hopeful results and to address the challenging issues.

\section{Acknowledgments}

The authors are grateful to Fondazione Luigi Califano, Fondazione Banco di Napoli, and Istituto Superiore di Sanità. The authors thank Prof Anna Maria Molinari and Prof Ferdinando Auricchio for helpful discussions.

\section{Disclosure}

The authors report no conflicts of interest in this work.

\section{References}

1. Hirsch AT, Haskal ZJ, Hertzer NR, et al; for American Association for Vascular Surgery/Society for Vascular Surgery; Society for Cardiovascular Angiography and Interventions; Society for Vascular Medicine and Biology; Society of Interventional Radiology; ACC/ AHA Task Force on Practice Guidelines. ACC/AHA Guidelines for the Management of Patients with Peripheral Arterial Disease (lower extremity, renal, mesenteric, and abdominal aortic): a collaborative report from the American Associations for Vascular Surgery/Society for Vascular Surgery, Society for Cardiovascular Angiography and Interventions, Society for Vascular Medicine and Biology, Society of Interventional Radiology, and the ACC/AHA Task Force on Practice Guidelines (writing committee to develop guidelines for the management of patients with peripheral arterial disease); summary of recommendations. J Vasc Interv Radiol. 2006;17(9):1383-1397.
2. Norgren L, Hiatt WR, Dormandy JA, Nehler MR, Harris KA, Fowkes FG; for TASC (Trans Atlantic Inter-Society Consensus) II Working Group. Inter-society consensus for the management of peripheral arterial disease (TASC II). J Vasc Surg. 2007;45 Suppl S:S5-S67.

3. Procházka V, Gumulec J, Jalůvka F, et al. Cell therapy, a new standard in management of chronic critical limb ischemia and foot ulcer. Cell Transplant. 2010;19(11):1413-1424.

4. Thorgeirsson TE, Geller F, Sulem P, et al. A variant associated with nicotine dependence, lung cancer and peripheral arterial disease. Nature. 2008;452(7187):638-642.

5. Wilson AM, Sadrzadeh-Rafie AH, Myers J, et al. Low lifetime recreational activity is a risk factor for peripheral arterial disease. J Vasc Surg. 2011;54(2):427-432, 432. e1-432. e4.

6. Conrad MF, Crawford RS, Hackney LA, et al. Endovascular management of patients with critical limb ischemia. JVasc Surg. 2011; 53(4):1020-1025.

7. Saha SP, Whayne TF Jr, Mukherjee D. Current evidence for antithrombotic therapy after peripheral vascular interventions. Curr Vasc Pharmacol. Epub January 20, 2012.

8. Lessiani G, Vazzana N, Cuccurullo C, et al. Inflammation, oxidative stress and platelet activation in aspirin-treated critical limb ischaemia: beneficial effects of iloprost. Thromb Haemost. 2011;105(2): 321-328.

9. Volz KS, Miljan E, Khoo A, Cooke JP. Development of pluripotent stem cells for vascular therapy. Vascul Pharmacol. 2012;56(5-6):288-296.

10. Asahara T, Murohara T, Sullivan A, et al. Isolation of putative progenitor endothelial cells for angiogenesis. Science. 1997;275(5302):964-967.

11. Shi Q, Rafii S, Wu MH, et al. Evidence for circulating bone marrowderived endothelial cells. Blood. 1998;92(2):362-367.

12. Asahara T, Masuda H, Takahashi T, et al. Bone marrow origin of endothelial progenitor cells responsible for postnatal vasculogenesis in physiological and pathological neovascularization. Circ Res. 1999; 85(3):221-228.

13. Crosby JR, Kaminski WE, Schatteman G, et al. Endothelial cells of hematopoietic origin make a significant contribution to adult blood vessel formation. Circ Res. 2000;87(9):728-730.

14. Tateishi-Yuyama E, Matsubara H, Murohara T, et al; for Therapeutic Angiogenesis using Cell Transplantation Study Investigators. Therapeutic angiogenesis for patients with limb ischaemia by autologous transplantation of bone-marrow cells: a pilot study and a randomised controlled trial. Lancet. 2002;360(9331):427-435.

15. Esato K, Hamano K, Li TS, et al. Neovascularization induced by autologous bone marrow cell implantation in peripheral arterial disease. Cell Transplant. 2002;11(8):747-752.

16. Saigawa T, Kato K, Ozawa T, et al. Clinical application of bone marrow implantation in patients with arteriosclerosis obliterans, and the association between efficacy and the number of implanted bone marrow cells. Circ J. 2004;68(12):1189-1193.

17. Higashi Y, Kimura M, Hara K, et al. Autologous bone-marrow mononuclear cell implantation improves endothelium-dependent vasodilation in patients with limb ischemia. Circulation. 2004;109(10): 1215-1218.

18. Miyamoto M, Yasutake M, Takano H, et al. Therapeutic angiogenesis by autologous bone marrow cell implantation for refractory chronic peripheral arterial disease using assessment of neovascularization by 99 mTc-tetrofosmin (TF) perfusion scintigraphy. Cell Transplant. 2004; 13(4):429-437.

19. Huang PP, Li SZ, Han MZ, et al. Autologous transplantation of peripheral blood stem cells as an effective therapeutic approach for severe arteriosclerosis obliterans of lower extremities. Thromb Haemost. 2004;91(3):606-609.

20. Kawamura A, Horie T, Tsuda I, et al. Prevention of limb amputation in patients with limbs ulcers by autologous peripheral blood mononuclear cell implantation. Ther Apher Dial. 2005;9(1):59-63.

21. Lenk K, Adams V, Lurz P, et al. Therapeutical potential of blood-derived progenitor cells in patients with peripheral arterial occlusive disease and critical limb ischaemia. Eur Heart J. 2005;26(18):1903-1909. 
22. Huang P, Li S, Han M, Xiao Z, Yang R, Han ZC. Autologous transplantation of granulocyte colony-stimulating factor-mobilized peripheral blood mononuclear cells improves critical limb ischemia in diabetes. Diabetes Care. 2005;28(9):2155-2160.

23. Ishida A, Ohya Y, Sakuda H, et al. Autologous peripheral blood mononuclear cell implantation for patients with peripheral arterial disease improves limb ischemia. Circ J. 2005;69(10):1260-1265.

24. Durdu S, Akar AR, Arat M, Sancak T, Eren NT, Ozyurda U. Autologous bone-marrow mononuclear cell implantation for patients with Rutherford grade II-III thromboangiitis obliterans. J Vasc Surg. 2006;44(4):732-739.

25. Koshikawa M, Shimodaira S, Yoshioka T, et al. Therapeutic angiogenesis by bone marrow implantation for critical hand ischemia in patients with peripheral arterial disease: a pilot study. Curr Med Res Opin. 2006;22(4):793-798.

26. Arai M, Misao Y, Nagai H, et al. Granulocyte colony-stimulating factor: a noninvasive regeneration therapy for treating atherosclerotic peripheral artery disease. Circ J. 2006;70(9):1093-1098.

27. Miyamoto K, Nishigami K, Nagaya N, et al. Unblinded pilot study of autologous transplantation of bone marrow mononuclear cells in patients with thromboangiitis obliterans. Circulation. 2006;114(24): 2679-2684.

28. Kawamura A, Horie T, Tsuda I, et al. Clinical study of therapeutic angiogenesis by autologous peripheral blood stem cell (PBSC) transplantation in 92 patients with critically ischemic limbs. J Artif Organs. 2006;9(4):226-233.

29. Bartsch T, Brehm M, Zeus T, Kögler G, Wernet P, Strauer BE. Transplantation of autologous mononuclear bone marrow stem cells in patients with peripheral arterial disease (the TAM-PAD study). Clin Res Cardiol. 2007;96(12):891-899.

30. Huang PP, Yang XF, Li SZ, Wen JC, Zhang Y, Han ZC. Randomised comparison of G-CSF-mobilized peripheral blood mononuclear cells versus bone marrow-mononuclear cells for the treatment of patients with lower limb arteriosclerosis obliterans. Thromb Haemost. 2007;98(6): 1335-1342.

31. Kajiguchi M, Kondo T, Izawa H, et al. Safety and efficacy of autologous progenitor cell transplantation for therapeutic angiogenesis in patients with critical limb ischemia. Circ J. 2007;71(2):196-201.

32. Hernández P, Cortina L, Artaza H, et al. Autologous bone-marrow mononuclear cell implantation in patients with severe lower limb ischaemia: a comparison of using blood cell separator and Ficoll density gradient centrifugation. Atherosclerosis. 2007;194(2):e52-e56.

33. Saito S, Nishikawa K, Obata H, Goto F. Autologous bone marrow transplantation and hyperbaric oxygen therapy for patients with thromboangiitis obliterans. Angiology. 2007;58(4):429-434.

34. Matoba S, Tatsumi T, Murohara T, et al. Long-term clinical outcome after intramuscular implantation of bone marrow mononuclear cells (Therapeutic Angiogenesis by Cell Transplantation [TACT] trial) in patients with chronic limb ischemia. Am Heart J. 2008;156(5): 1010-1018.

35. Napoli C, Farzati B, Sica V, et al. Beneficial effects of autologous bone marrow cell infusion and antioxidants/L-arginine in patients with chronic critical limb ischemia. Eur J Cardiovasc Prev Rehabil. 2008; 15(6):709-718.

36. Gu YQ, Zhang J, Guo LR, et al. Transplantation of autologous bone marrow mononuclear cells for patients with lower limb ischemia. Chin Med J (Engl). 2008;121(11):963-967.

37. Chochola M, Pytlík R, Kobylka P, et al. Autologous intra-arterial infusion of bone marrow mononuclear cells in patients with critical leg ischemia. Int Angiol. 2008;27(4):281-290.

38. Wester T, Jørgensen JJ, Stranden E, et al. Treatment with autologous bone marrow mononuclear cells in patients with critical lower limb ischaemia: a pilot study. Scand J Surg. 2008;97(1):56-62.

39. Van Tongeren RB, Hamming JF, Fibbe WE, et al. Intramuscular or combined intramuscular/intra-arterial administration of bone marrow mononuclear cells: a clinical trial in patients with advanced limb ischemia. J Cardiovasc Surg (Torino). 2008;49(1):51-58.
40. De Vriese AS, Billiet J, Van Droogenbroeck J, Ghekiere J, De Letter JA. Autologous transplantation of bone marrow mononuclear cells for limb ischemia in a Caucasian population with atherosclerosis obliterans. J Intern Med. 2008;263(4):395-403.

41. Cobellis G, Silvestroni A, Lillo S, et al. Long-term effects of repeated autologous transplantation of bone marrow cells in patients affected by peripheral arterial disease. Bone Marrow Transplant. 2008;42(10): 667-672.

42. Motukuru V, Suresh KR, Vivekanand V, Raj S, Girija KR. Therapeutic angiogenesis in Buerger's disease (thromboangiitis obliterans) patients with critical limb ischemia by autologous transplantation of bone marrow mononuclear cells. J Vasc Surg. 2008;48(Suppl 6): S53-S60.

43. Amann B, Lüdemann C, Rückert R, et al. Design and rationale of a randomized, double-blind, placebo-controlled phase III study for autologous bone marrow cell transplantation in critical limb ischemia: the BONe Marrow Outcomes Trial in Critical Limb Ischemia (BONMOT-CLI). Vasa. 2008;37(4):319-325.

44. Amann B, Lüdemann C, Ratei R, Schmidt-Lucke JA. Autologous bone marrow cell transplantation increases leg perfusion and reduces amputations in patients with advanced critical limb ischemia due to peripheral artery disease. Cell Transplant. 2009;18(3):371-380.

45. Capiod JC, Tournois C, Vitry F, et al. Characterization and comparison of bone marrow and peripheral blood mononuclear cells used for cellular therapy in critical leg ischaemia: towards a new cellular product. Vox Sang. 2009;96(3):256-265.

46. Franz RW, Parks A, Shah KJ, Hankins T, Hartman JF, Wright ML. Use of autologous bone marrow mononuclear cell implantation therapy as a limb salvage procedure in patients with severe peripheral arterial disease. J Vasc Surg. 2009;50(6):1378-1390.

47. Franz RW, Shah KJ, Johnson JD, et al. Short- to mid-term results using autologous bone-marrow mononuclear cell implantation therapy as a limb salvage procedure in patients with severe peripheral arterial disease. Vasc Endovascular Surg. 2011;45(5):398-406.

48. Zafarghandi MR, Ravari H, Aghdami N, et al. Safety and efficacy of granulocyte-colony-stimulating factor administration following autologous intramuscular implantation of bone marrow mononuclear cells: a randomized controlled trial in patients with advanced lower limb ischemia. Cytotherapy. 2010;12(6):783-791.

49. Procházka V, Gumulec J, Chmelová J, et al. Autologous bone marrow stem cell transplantation in patients with end-stage chronical critical limb ischemia and diabetic foot. Vnitr Lek. 2009;55(3):173-178.

50. Lara-Hernandez R, Lozano-Vilardell P, Blanes P, Torreguitart-Mirada N, Galmés A, Besalduch J. Safety and efficacy of therapeutic angiogenesis as a novel treatment in patients with critical limb ischemia. Ann Vasc Surg. 2010;24(2):287-294.

51. Iso $\mathrm{Y}$, Soda $\mathrm{T}$, Sato $\mathrm{T}$, et al. Impact of implanted bone marrow progenitor cell composition on limb salvage after cell implantation in patients with critical limb ischemia. Atherosclerosis. 2010;209(1): $167-172$.

52. Sprengers RW, Moll FL, Teraa M, Verhaar MC; for JUVENTAS Study Group. Rationale and design of the JUVENTAS trial for repeated intra-arterial infusion of autologous bone marrow-derived mononuclear cells in patients with critical limb ischemia. J Vasc Surg. 2010;51(6): 1564-1568.

53. Murphy MP, Lawson JH, Rapp BM, et al. Autologous bone marrow mononuclear cell therapy is safe and promotes amputation-free survival in patients with critical limb ischemia. J Vasc Surg. 2011;53(6): 1565-1574.

54. Walter DH, Krankenberg H, Balzer JO, et al. Intraarterial administration of bone marrow mononuclear cells in patients with critical limb ischemia: a randomized start, placebo-controlled pilot trial (PROVASA). Circ Cardiovasc Interv. 2011;4(1):26-37.

55. Iafrati MD, Hallett JW, Geils G, et al. Early results and lessons learned from a multicenter, randomized, double-blind trial of bone marrow aspirate concentrate in critical limb ischemia. JVasc Surg. 2011;54(6): $1650-1658$. 
56. Idei N, Soga J, Hata T, et al. Autologous bone-marrow mononuclear cell implantation reduces long-term major amputation risk in patients with critical limb ischemia: a comparison of atherosclerotic peripheral arterial disease and Buerger disease. Circ Cardiovasc Interv. 2011;4(1): $15-25$.

57. Ruiz-Salmeron R, de la Cuesta-Diaz A, Constantino-Bermejo M, et al. Angiographic demonstration of neoangiogenesis after intra-arterial infusion of autologous bone marrow mononuclear cells in diabetic patients with critical limb ischemia. Cell Transplant. 2011;20(10): $1629-1639$.

58. Lu D, Chen B, Liang Z, et al. Comparison of bone marrow mesenchymal stem cells with bone marrow-derived mononuclear cells for treatment of diabetic critical limb ischemia and foot ulcer: a double-blind, randomized, controlled trial. Diabetes Res Clin Pract. 2011;92(1): 26-36.

59. Gabr H, Hedayet A, Imam U, Nasser M. Limb salvage using intramuscular injection of unfractionated autologous bone marrow mononuclear cells in critical limb ischemia: a prospective pilot clinical trial. Exp Clin Transplant. 2011;9(3):197-202.

60. Benoit E, O'Donnell TF Jr, Iafrati MD, et al. The role of amputation as an outcome measure in cellular therapy for critical limb ischemia: implications for clinical trial design. J Transl Med. 2011;9:165.

61. Powell RJ, Comerota AJ, Berceli SA, et al. Interim analysis results from the RESTORE-CLI, a randomized, double-blind multicenter phase II trial comparing expanded autologous bone marrow-derived tissue repair cells and placebo in patients with critical limb ischemia. J Vasc Surg. 2011;54(4):1032-1041.

62. Perin EC, Silva G, Gahremanpour A, et al. A randomized, controlled study of autologous therapy with bone marrow-derived aldehyde dehydrogenase bright cells in patients with critical limb ischemia. Catheter Cardiovasc Interv. 2011;78(7):1060-1067.

63. Smadja DM, Duong-van-Huyen JP, Dal Cortivo L, et al. Early endothelial progenitor cells in bone marrow are a biomarker of cell therapy success in patients with critical limb ischemia. Cytotherapy. 2012;14(2):232-239.

64. Powell RJ, Marston WA, Berceli SA, et al. Cellular therapy with ixmyelocel-T to treat critical limb ischemia: the randomized, doubleblind, placebo-controlled RESTORE-CLI trial. Mol Ther. 2012;20(6): 1280-1286.

65. Klepanec A, Mistrik M, Altaner C, et al. No difference in intraarterial and intramuscular delivery of autologous bone-marrow cells in patients with advanced critical limb ischemia. Cell Transplant. Epub April 2, 2012.

66. Schiavetta A, Maione C, Botti C, et al. A phase II trial of autologous transplantation of bone marrow stem cells for critical limb ischemia: results of NAPLES study. Stem Cells Trans Med. In press 2012

67. Vojtassák J, Danisovic L, Kubes M, et al. Autologous biograft and mesenchymal stem cells in treatment of the diabetic foot. Neuro Endocrinol Lett. 2006;27 Supp1 2:S134-S137.

68. Dash NR, Dash SN, Routray P, Mohapatra S, Mohapatra PC. Targeting nonhealing ulcers of lower extremity in human through autologous bone marrow-derived mesenchymal stem cells. Rejuvenation Res. 2009; 12(5):359-366.
69. Subrammaniyan R, Amalorpavanathan J, Shankar R, et al. Application of autologous bone marrow mononuclear cells in six patients with advanced chronic critical limb ischemia as a result of diabetes: our experience. Cytotherapy. 2011;13(8):993-999.

70. Carmeliet P. Angiogenesis in health and disease. Nat Med. 2003;9(6): 653-660.

71. Benoit E, O'Donnell TF Jr, Patel AN. Safety and efficacy of autologous cell therapy in critical limb ischemia: a systematic review of the literature. Cell Transplant. Epub March 28, 2012.

72. Kaelin WG Jr, Ratcliffe PJ. Oxygen sensing by metazoans: the central role of the HIF hydroxylase pathway. Mol Cell. 2008;30(4):393-402.

73. Gopall J, Huang W, Zhao Y. Prospects of adult stem cells therapy in peripheral vascular diseases. BJMP. 2010;3(4):a345.

74. Dimmeler S, Burchfield J, Zeiher AM. Cell-based therapy of myocardial infarction. Arterioscler Thromb Vasc Biol. 2008;28(2):208-216.

75. Cobellis G, Maione C, Botti C, et al. Beneficial effects of VEGF secreted from stromal cells in supporting endothelial cell functions: therapeutic implications for critical limb ischemia. Cell Transplant. 2010;19(11):1425-1437.

76. Volarevic V, Arsenijevic N, Lukic ML, Stojkovic M. Concise review: mesenchymal stem cell treatment of the complications of diabetes mellitus. Stem Cells. 2011;29(1):5-10.

77. Pittenger MF, Mackay AM, Beck SC, et al. Multilineage potential of adult human mesenchymal stem cells. Science. 1999;284(5411):143-147.

78. Aggarwal S, Pittenger MF. Human mesenchymal stem cells modulate allogeneic immune cell responses. Blood. 2005;105(4):1815-1822.

79. Stagg J. Immune regulation by mesenchymal stem cells: two sides to the coin. Tissue Antigens. 2007;69(1):1-9.

80. Ribatti D, Nico B, Crivellato E. The role of pericytes in angiogenesis. Int J Dev Biol. 2011;55(3):261-268.

81. Schatteman GC, Awad O. Hemangioblasts, angioblasts, and adult endothelial cell progenitors. Anat Rec A Discov Mol Cell Evol Biol. 2004;276(1):13-21.

82. Jarajapu YP, Grant MB. The promise of cell-based therapies for diabetic complications: challenges and solutions. Circ Res. 2010; 106(5):854-869.

83. Dormandy JA, Murray GD. The fate of the claudicant: a prospective study of 1969 claudicants. Eur J Vasc Surg. 1991;5(2):131-133.

84. Criqui MH, Langer RD, Fronek A, et al. Mortality over a period of 10 years in patients with peripheral arterial disease. $N$ Engl J Med. 1992;326(6):381-386.

85. Hirsch AT, Criqui MH, Treat-Jacobson D, et al. Peripheral arterial disease detection, awareness, and treatment in primary care. JAMA. 2001;286(11):1317-1324.

86. Dormandy JA, Rutherford RB; for Trans Atlantic Inter-Society Consensus Working Group. Management of peripheral arterial disease (PAD). J Vasc Surg. 2000;31(1 Pt 2):S1-S296.

87. Fowkes FG, Housley E, Cawood EH, Macintyre CC, Ruckley CV, Prescott RJ. Edinburgh Artery Study: prevalence of asymptomatic and symptomatic peripheral arterial disease in the general population. Int $J$ Epidemiol. 1991;20(2):384-392.
Stem Cells and Cloning: Advances and Applications

\section{Publish your work in this journal}

Stem Cells and Cloning: Advances and Applications is an international, peer-reviewed, open access journal. Areas of interest in stem cell research include: Embryonic stem cells; Adult stem cells; Blastocysts; Cordblood stem cells; Stem cell transformation and culture; Therapeutic cloning; Umbilical cord blood and bone marrow cells; Laboratory,

\section{Dovepress}

animal and human therapeutic studies; Philosophical and ethical issues related to stem cell research. This journal is indexed on CAS. The manuscript management system is completely online and includes a quick and fair peer-review system. Visit http://www.dovepress.com/ testimonials.php to read real quotes from published authors. 